\title{
Penggunaan Bahasa Melayu Ambon sebagai Bahasa Pertama Memengaruhi Kemampuan Berbahasa Indonesia Peserta Didik Kelas VIII SMP Negeri 7 Ambon
}

\author{
Iwan Rumalean', Yohanes Hukubun², Muhammad Akbar Kosu ${ }^{3}$ \\ Universitas Pattimura \\ iwan197577@gmail.com¹, hukanes@gmail.com².
}

DOI: https://doi.org/10.32528/bb.v6i1.4055

First received: 08-01-2021

Final proof received: $28-02-2021$

\begin{abstract}
ABSTRAK
Pelaksanaan penelitian ini bertujuan mengeksplanasi penggunaan bahasa Melayu Ambon (BMA) sebagai bahasa ibu (B1) memengaruhi kemampuan berbahasa Indonenesia sebagai bahasa kedua (B2) peserta didik kelas VIII SMP Negeri 7 Ambon. Linguistik sinkronis digunakan sebagai dan jenis penelitian kualitatif deskriptif. Lokasi penelitian SMP Negeri 7 Ambon Jl. dr. J. Leimena Wailela Ambon. Subjek penelitian 25 peserta didik dan 1 orang guru mata pelajaran bahasa Indonesia. Data berupa tuturan lisan dalam proses pembelajaran dan data tulisan berupa karangan deskripsi karya peserta didik. Pengumpulan data menggunakan teknik wawancara tidak terstruktur dan observasi deskriptif. Instrumen pengumpulan data, human instrument, daftar pertanyaan, catatan, dan rekaman. Analisis data menggunakan, (1) teknik kategorisasi, (2) teknik interpretasi, dan (3) teknik penyimpulan. Pemeriksaan data penelitian digunakan teknik triangulasi. Hasil penelitian menunjukan, BMA merupakan bahasa pertama (B1) dan bahasa Indonesia sebagai B2 bagi peserta didik dan guru SMP Negeri 7 Ambon. BMA maupun bahasa Indonesia dikuasai dan digunakan secara bersamaan dalam pembelajaran. BMA sebagai bahasa Ibu (B1) memengaruhi bahasa Indonesia sebagai bahasa kedua (B2). Latar belakang penggunaan BMA di dalam proses pembelajaran atau situasi formal disebabkab oleh faktor kedwibahasaan dan faktor migrasi serta urbanisasi penduduk di Kota Ambon. Untuk menyiasati agar peserta didik menggunakan bahasa Indonesia dalam situasi formal, maka guru harus menjadi suri tauladan (role model) bagi peserta didik.
\end{abstract}

Kata kunci: Penggunaan B1; B2; pembelajaran bahasa Indonesia

\begin{abstract}
Aim to explain the use of Ambonese Malay Language (AML) as the mother tongue (L1) affecting the ability to speak Indonesian as a second language (L2) in learning Indonesian for Class VIII Students of SMP Negeri 7 Ambon. This study uses a synchronic linguistic approach with descriptive qualitative research. Research location SMP Negeri 7 Ambon Jl. dr. J. Leimena Wailela Ambon. The research subjects were 25 students
\end{abstract}


and 1 Indonesian language subject teacher. Data in the form of oral speech in the learning process and written data were obtained from essay descriptions written by students. Data collection using unstructured interview techniques and descriptive observation. Data collection instruments were human instruments, questionnaires, notes, and recordings. Data analysis techniques, (1) categorization, (2) interpretation, and (3) inference. The research data examination used the triangulation technique. The results showed, BMA is the first language (B1) and Indonesian is B2 for students and teachers of SMP Negeri 7 Ambon. BMA and Indonesian are mastered and used simultaneously in learning (bilingual). BMA as the Mother Language (L1) affects Indonesian as a second language (L2) in the learning process. Students use BMA in the learning process or formal situations, motivated by bilingual factors and population migration factors in Ambon City. To get around students using Indonesian informal situations, the teacher must be a role model for students.

Keywords: the use of L1, L2, Indonesian language learning.

\section{PENDAHULUAN}

Bahasa Melayu Ambon (BMA) merupakan bahasa Ibu atau bahasa pertama (B1) bagi masyarakat yang lahir dan besar di Kota Ambon. Konsep bahasa Ibu (B1) adalah bahasa yang pertama kali dikuasai oleh seseorang sejak kecil bukan atau belum tentu bahasa yang digunakan oleh ibu yang melahirkan. Misalnya, ibu kandung berbahasa Inggris, putra dari ibu kandung tersebut sejak lahir diasuh oleh kakeknya yang berbahasa Indonesia. Putra tersebut pertama kali berbahasa dan selanjutnya menguasai bahasa Indonesia, maka bahasa ibu (B1) putra tersebut adalah bahasa Indonesia bukan bahasa Inggris.

Berdasarkan wawancara dengan 25 peserta didik, bahwa bahasa yang dikuasai pertama kali adalah BMA dan setelah itu bahasa Indonesia. Dengan demikian, B1 25 peserta didik pada kelas VIII SMP Negeri 7 Ambon adalah BMA dan B2 adalah bahasa Indonesia.

Selain sebagai B1, BMA juga merupakan lingua franca bagi masyarakat Kota Ambon termasuk siswa kelas VIII SMP Negeri 7 Ambon yang berasal dari etnik lokal seperti masyarakat dari Maluku Barat Daya, Masyarakat Kepulauan Tanimbar, Masyarakat Kepulauan Kei, Masyarakat Kepulauan Banda, masyarakat Pulau Seram, Leasi dan pulau Ambon serta etnik lain yang berasal dari berbagai wilayah di Indonesia.

Penggunaan BMA sebagai B1 dan sebagai lingua franca memiliki dampak pengiring dalam penggunaan bahasa Indonesia bagi peserta didik pada kelas VIII SMP Negeri 7 Ambon. Sebagaimana dialami oleh anak berusia 2 s.d 6 tahun di Desa Holimombo Jaya yang berkomunikasi menggunakan bahasa Ciacia dan bahasa Indonesia (Nurlaila, 2016).

Berdasarkan hasil wawancara dengan 25 peserta didik pada kelas VIII SMP Negeri 7 Ambon tampak bahwa BMA telah teraneksasi dalam berbagai segi kehidupan. Penggunaan BMA oleh peserta didik, dapat dipahami sebagai akibat dari kedwibahasaan yang dimiliki oleh peserta didik. Sebagaimana dijelaskan pada oleh Rumalean dkk., (2020) pada contoh berikut ini, (1) ibu, beta deng Lidya jua e...'Ibu, saya bersama Lidya saja", (2) ambe aja "ambil saja", dan (3) se sanang sekali e... "Anda sangat senang".

Penggunaan kosakata pada kalimat nomor satu, terdiri atas dua bentuk, yaitu kosakata bahasa Indonesia dan kosakata BMA. Kata "ibu" pada contoh nomor 1 dalam 
BMA sehari-sehari yang digunakan adalah "mama", dengan demikian peserta didik menggunakan kata "ibu" merupakan kosakata bahasa Indonesia yang dirangkai dengan bentuk beta deng Lidya jua adalah bentuk BMA. Kosakata pada kalimat nomor 2, terdiri atas dialek Jakarta dan BMA. Kosakata ambe "ambil" adalah bentuk kosakata BMA. Bentuk aja adalah kosakata dialek Jakarta yang artinya "saja". Pada kalimat nomor 3, deretan kosakata se sanang e...adalah bentuk BMA. Bentuk senang adalah bentuk kosakata bahasa Indonesia.

Penggunaan BMA, dialek Jakarta, dan bahasa Indonesia pada penjelasan tersebut sebagai pertanda kedwibahasaan dominan bagi peserta didik dalam pembelajaran. Selain kedwibahasawan, hasil wawancara terhadap 25 peserta didik, 20 diantaranya mengatakan bahwa penggunaan dialek Jakarta sebagai sebuah prestise orang kota, atau orang yang erat dengan Jakarta sebagai ibu kota Negara Indonesia. Namun demikian, penggunaan dialek daerah dalam proses pembelajaran sebaiknya diperbaiki terus-menerus. Sehingga bahasa baku yang diamanatkan UU Nomor 24 tahun 2009, bahasa Indonesia wajib digunakan dalam situasi resmi termasuk dalam proses pembelajaran.

Fenomena penggunaan BMA, bahasa Indonesia, dan dialek Jakarta sebagaimana penjelasan paragraf sebelumnya, maka yang menjadi pertanyaan adalah apakah BMA memengaruhi bahasa Indonesia atau sebaliknya?, atau saling memengaruhi?. Fenomena dan pertanyaan tersebut menjadi dasar pelaksanaan penelitian ini. Selanjutnya, rumusan masalah penelitian ini adalah 'bagaimanakah Penggunaan BMA sebagai bahasa Ibu (B1) memengaruhi kemampuan berbahasa Indonesia (B2) dalam hasil pembelajaran bahasa Indonesia siswa kelas VIII SMP Negeri 7 Ambon?".

Kemampuan berbahasa Indonesia merupakan upaya yang dilakukan oleh peserta didik dan guru agar menggunakan bahasa Indonesia secara baik dan benar. Kusmawanto, dkk, (2019, hal 462) menjelaskan bahwa kemampuan berbahasa Indonesia di sekolah meliputi empat keterampilan berbahasa yaitu (1) mendengarkan atau menyimak, (2) berbicara, (3) membaca, dan (4) menulis. Keterampilan mendengar dan berbicara bersifat lisan atau oral dan reseptif. Keterampilan membaca dan menulis merupakan keterampilan yang bersifat produktif yang menghasilkan sesuatu berupa tulisan.

Penelitian ini bertujuan mengeksplanasi penggunaan BMA sebagai B1 memengaruhi kemampuan berbahasa Indonesia sebagai B2. Penelitian penggunaan B1 dan B2 bukan merupakan isu baru dalam bidang penelitian kebahasaan. Untuk itu perlu dikemukakan beberapa penelitian terdahulu relevan namun berbeda dari berbagai aspek, sehingga duplikasi dapat dihindari. Dengan demikian, ada hal baru yang disumbangkan dari penelitian ini. Penelitian terdahulu tersebut sebagaimana penjelasan di bawa ini.

Penguasaan leksikon arkais BMA di kalangan pemuda di Kota Ambon diteliti Erniati (2019). Penelitian tersebut menggunakan jenis penelitian eksperimental dengan pendekatan kuantitatif. Dengan demikian, penelitian BMA yang dilakukan Erniati berbeda dengan penelitian ini bila dilihat dari pendekatan, jenis penelitian, dan hasil yang diperoleh.

Penelitian relefan selanjutnya adalah yang dilakukan Rumalean, dkk., (2020) dengan judul yang Analisis Pemerolehan Kesalahan Berbahasa dalam Pembelajaran bahasa Indonesia pada Peserta Didik Kelas VIII SMP Negeri 7 Ambon. Tujuan penelitian tersebut adalah untuk menganalisis pemerolehan kesalahan berbahasa peserta didik dalam pembelajaran bahasa Indonesia. Berbeda dengan penelitian ini adalah dalam hal tujuan penelitian. Penelitian Rumalean dkk, (2020) menganalisis kesalahan berbahasa, sedangkan penelitian ini berusaha mengeksplanasi penggunaan BMA sebagai B1 memengaruhi penggunaan bahasa Indonesia sebagai B2. Dengan demikian subtansi dari kedua penelitian tersebut berbeda. 


\section{METODE PENELITIAN}

Jenis penelitian yang digunakan adalah kualitatif deskriptif dengan pendekatan linguistik sinkronis. Penelitian ini berlokasi di SMP Negeri 7 Ambon Jalan Dr. Johanes Leimena Desa Rumah Tiga -Wailela Kota Ambon. Subjek penelitian sebanyak 25 peserta didik dan 1 orang guru mata pelajaran bahasa Indonesia. Data penelitian berupa karangan deskripsi yang ditulis oelh peserta didik dan tuturan lisan dalam proses pembelajaran. Data tersebut dianalisis untuk menjelaskan masalah penelitian.

Data penelitian dikumpulkan melalui metode wawancara tidak terstruktur dan observasi deskriptif (Syamsudin dan Damaianti, 2006 hal 102), dan teknik baca serta catat. Wawancara peserta didik untuk diperoleh data tentang bahasa yang dikuasai sebelum berusia sekolah hingga sekolah, dan alasan menggunakan bahasa atau dialek selain BMA. Metode observasi digunakan untuk mengobservasi penggunaan bahasa lisan peserta didik dalam proses pembelajaran. Selanjutnya, teknik baca-catat digunakan untuk membaca dan mencatat penggunaan kosakata dan kalimat BMA serta bahasa Indonesia dalam karangan deskripsi yang ditulis oleh peserta didik.

Instrumen pengumpulan data yang digunakan terdiri atas dua yaitu, human instrument dan daftar pertanyaan. Human instrument dalam penelitian ini adalah peneliti. Sehingga peneliti melibatkan diri secara langsung dengan peserta didik dan guru dalam proses wawancara (Sugiyono, 2006 hal 249-251). Selain human instrument, peneliti juga menggunakan catatan dan rekaman dengan menggunakan kamera HP Vivo tipe Y95.

Pada tahapan analisis data digunakan teknik deskriptif. Tekhnik tersebut dilalui dengan tiga tahapan, yaitu (1) pengategorisasian data, (2) penginterpretasian data, dan (3) penyimpulan data. Penahapan penganalisisan tersebut berlangsung secara daur yang dimulai sejak perencanaan penelitian yang diawali dengan pengumpulan data, reduksi data, pemaparan data, dan verifikasi. Selanjutnya disimpulkan secara deskriptif kemudian pelaporan hasil disesuaikan dengan kebutuhan (baca Rumalean, dkk., 2020).

Selanjutnya, untuk pemeriksaan data penelitian, terdapat 5 dari delapan strategi yang diusulkan Creswell (2015, hal 349-352), bahwa penelitian kualitatif melibatkan paling tidak dua prosedur dalam studi kualitatif apapun yang dilaksanakan. Dari delapan prosedur tersebut, Creswell merekomendasikan prosedur triangulasi dengan beragam sumber data dianggap paling representatif mewakili tuju prosedur yang lain. Penggunaan triangulasi data dilakukan pengujian silang data rekaman dengan wawancara, atau antara data wawancara dengan rekaman atau pun dengan data hasil angket/kuesioner.

\section{PEMBAHASAN}

\section{a. Hasil}

1. Penggunaan BMA sebagai B1 dan Bahasa Indonesia sebagai B2 dalam Ranah Lisan.

Berdasarkan analisis data yang diperoleh melalui tuturan dalam proses pembelajaran bahasa Indonesia pada peserta didik kelas VIII SMP Negeri 7 Ambon didominasi oleh Bahasa Melayu Ambon (BMA) sebagai B1 yang diikuti dengan bahasa Indonesia sebagai B2. Sedangkan B3 dan seterusnya belum tampak dalam tuturan.

BMA sebagai B1 mendominasi dalam tuturan, kemudian diikuti dengan bahasa Indonesia. Hal tersebut tampak pada data penggunaan B1 dan B2 pada (PB1PB2) 1 berikut ini.

Tutur 1, A : Silahkan kalian mempelajari materi dan kerjakan tugas pada teks yang ibu berikan. 
Tutur 2, B, C, D... : : Ia Ibu

Tutur 3, B : Ibu, katong kerja dengan teman ka sandiri-sandiri?

Tutur 4, A : Kalian mengerjakan secara perorangan ya.

Tutur 5, B, C, D... : : Ia Ibu

Tutur 6, B : Lusi, se pung dunia suda

Tutur 7, C : Jang baribot

Tutur 8, A : Tenang ya, saya harap kalian kerja dengan baik dan jang main-main.

Tutur, B, C, D, E... : Ia ibu, trimakasih.

\section{Keterangan:}

A : Guru

B, C, D, E... : : Siswa

Situasi : proses mengerjakan soal latihan bahasa Indonesia topik menulis petunjuk.

Kosakata yang gunakan oleh guru pada dialog PB1PB2 1 tersebut menunjukan dominasi bahasa Indonesia. Berbanding terbalik dengan peserta didik, yaitu BMA mendominasi tuturan. Dengan demikian, jumlah kosakata yang digunakan oleh guru lebih banyak, namun sedikit unsur BMA. Sebaliknya, siswa sedikit menggunakan kosakata dan banyak terdapat unsur BMA.

Berdasarkan data PB1PB2 1 tersebut, peserta didik menggunakan BMA dan bahasa Indonesia pada situasi resmi yaitu situasi pembelajaran di kelas. Pada sisi yang lain, guru sebagai role model berusaha menggunakan bahasa Indonesia secara baik dan benar. Bentuk kata BMA diantara 28 kosakata yang digunakan oleh guru merupakan bagian dari siasat komunikasi, dengan tujuan agar terjadi keakraban dengan peserta didik. Selain data penggunaan BMA dan bahasa Indonesia tersebut, terdapat data pembanding yang lain sebagaimana berikut ini.

\section{PB1PB2, 2.}

Tutur 1, C

Tutur 2, E,F

Tutur 3, A

Tutur $4, \mathrm{~B}, \mathrm{C}, \mathrm{D}, \ldots$

Tutur 5, B

Tutur 6, G

Tutur 7, A

Tutur 8, B, C, D...

Tutur $9, \mathrm{~B} \ldots$.

Tutur 10, F

Tutur 11, A

Tutur 11, B, C D..
: Ibu, saya su selesai kerja

: saya juga ibu (dua siswa hampir bersamaan memberitahu ibu guru)

: baik kita menunggu yang lain ya?

: Ia ibu (siswa menjawab serentak)

: saya sudah ibu.

: beta lai sudah, ibu.

: baik, jika semua sudah siap silahkan dikumpulkan

: Ia Ibu (Serentak)

: sadiki lai ibu (suara pelan, memohon pada ibu guru untuk diberi tambahan waktu).

: jang baribot (ketua kelas memeringatkan anggota kelas).

: tenang ya, jika Anda semua telah mengumpulkan pekerjaan, maka pembelajaran pada hari ini kita akhiri ya.

: selamat siang ibu.

\section{Keterangan:}

A

$\mathrm{B}, \mathrm{C} \mathrm{D}$

PB1PB2
: Guru

: Siswa

: Penggunaan BMA (B1) dan

bahasa Indonesia B2. 
Kata bergaris bawah : adalah bentuk kosakata BMA.

Berdasarkan data PB1PB2, 2 memperkuat data PB1PB2 2. Kosakata bahasa Indonesia oleh guru didominasi oleh bahasa Indonesia. Sebaliknya BMA sebagai bahasa pertama masih mendominasi tutran peserta didik. Berdasarkan penjelasan tersebut, dominasi penggunaan BMA digunakan berbarengan dengan Bahasa Indonesia oleh peserta didik pada kelas VIII SMP Negeri 7 Ambon. Peristia berbahasa secara berbarengan dua bahasa atau lebih pada suatu tuturan, maka hal tersebut menunjukan peristiwa bilingualisme. Seharusnya dalam situasi pembelajaran yang formal kosakata yang digunakan adalah bahasa Indonesia dalam jumlah dominan.

\section{Penggunaan BMA sebagai B1 dan Bahasa Indonesia sebagai B2 dalam Ranah Tulisan}

Berdasarkan karangan deskripsi peserta didik pada kelas VIII SMP Negeri 7 Ambon, ditemukan beberapa bentuk BMA dan bahasa Indonesia. Misalnya, "di rumah saya ada juga grasi saya di samping rumah". Penggunaan kata "rumah" yang lebih dari satu kali dalam secara tidak hemat dalam kalimat tersebut merupakan bentuk pengaruh bentuk BMA. Penggunaan BMA umumnya lisan, sehingga tidak terikat dengan struktur. Pola lisan BMA menjadi habitus lisan berpengaruh dalam Bahasa Indonesia formal. Dilihat dari segi struktur kalimat yang digunakan, berpola S-O-Ket, bentuk tersebut dipengaruhi oleh bentuk BMA ...di beta rumah, ada grasi di sabla rumah. Pola struktur BMA tidak mengenal bentuk rumah beta tetapi beta rumah atau beta pung rumah. Struktur kalimat tersebut semestinya diefektifkan melalui pola S-P-O-K ...saya bermukim di Jl. dr. J. Leimena Desa Wayame. Sebelah Utara, berbatasan dengan jalan raya, ada garasi mobil.

Selain pola struktur kalimat, terdapat pula pengaruh bentuk yang lain yaitu penggunaan preposisi [di-] pada awal paragraf yang tidak efektif pada cuplikan berikut. Misalnya pada kaliamt "di rumah saya" ....."di lantai 2 ada 4 kamar, ...dan di lantai 1 ada 4 kamar". Penggunaan preposisi [di-] pada kalimat tersebut merupakan habitus struktur BMA sebagaimana berikut ini “...di beta pung rumah atau ...di beta rumah. Posisi preposisi [di-] tidak efektif menduduki awal paragraf. Preposisi [di-] berfungsi mendahului objek keterangan seperti tempat atau alamat. Kata rumah pada kalimat tersebut, bukan berlaku sebagai tempat atau alamat. Oleh karena itu, kalimat tersebut diefektifkan menjadi, “...rumah saya terletak di Jalan dr. J. Leimena Desa Wayame. Rumah saya memiliki 8 kamar, 4 berada di lantai 1 dan 4 berada di lantai 2...."

Penggunaan preposisi [di-] pada teks tersebut berbeda dengan preposisi [di-] pada kalimat, misalnya "di pinggir pantai", "di pinggir hutan/gunung. Kadang-kadang saja" Penggunaan preposisi [di-] pada kalimat deskripsi tersebut merupakan bentuk yang tepat, karena [di-] sebagai preposisi berspasi dengan klausa [-pinggir pantai] yang merupakan objek. Bentuk seperti itu terdapat pada bentuk kalimat berikut "di pinggir hutan/gunung". Selanjutnya, terdapat juga bentuk penggunaan bahasa Indonesia yang dipengaruhi oleh unsur BMA sebagaimana kosakata daera "daerah" dan kata ulang daera-daera "daerahdaerah". Peserta didik menggunakan kata "daerah" dan kata ulang "daera-daera". Kata "daerah" pada suku kata kedua diakhiri dengan fonem [-h] sebagai bentuk yang baku. Sedangkan yang tidak menggunakan fonem [-h] merupakan bentuk yang tidak baku. Penggunaan kata ulang daera-daera (tanpa fonem [-h]) sebanyak tiga kali merupaka sebuah kekonsistenan. Dengan demikian, penggunaan kata ulang "daera-daera" tanpa [h] pada kata kedua sampai keempat merupakan bentuk yang benar menurut peserta 07 . Akan tetapi bentuk kata ulang bahasa Indonesia yang baku adalah daerah-daerah yang 
diakhiri fonem [-h]. Sedangkan tanpa [-h] adalah bentuk yang tidak Baku (KBBI, versi daring 2.8, 2019).

Berbeda dengan penggunaan kata daera tanpa fonem [-h] yang digunakan oleh peserta didik 08 dalam karang deskripsi. Misalnya, "daera". Kata daera tanpa fonem [h] dalam karangan deskripsi tersebut berjumlah satu. Oleh karena cuma satu, maka tidak dapat dikategorikan sebagai kesalahan (error) tetapi sebagai kekeliruan (mistake), karena tidak terdapat unsur kekonsistenan. Dikategorikan sebagai tindakan kekonsistenan apabila kata yang salah itu digunakan secara berulang-ulang dalam jumlah yang lebih dari satu kali.

Penggunaan bahasa Indonesia yang dipengaruhi oleh BMA yang lain dalam hal pemborosan kata (mubazir) seperti pada kata ulang teman-teman dan kata banyak. Penggunaan kata bahasa Indonesia "teman-teman" merupakan bentuk ulang dari nomina dasar "teman". Dalam BMA diujarkan tamang-tamang yang bermakna nominal jamak. Dengan demikian, kata "teman-teman" dalam kalimat tersebut bermakna teman atau sahabat yang berjumlah lebih dari satu orang, berarti maknanya persis dengan kata "banyak" pada (KBBI, versi daring 2.8, 2019).

Berdasarkan penjelasan tersebut, kata ulang "teman-teman" dan "banyak" bermakna nominal jamak. Penggunaan kedua unsur tersebut merupakan bentuk pengaruh BMA terhadap bahasa Indonesia yaitu beta pung tamang-tamang "teman-teman saya" yang secara nominal berbeda dengan bentuk BMA beta tamang atau beta pung tamang yang makna nominalnya satu teman (tidak lebih dari).

Penggunaan kosakata yang berkemiripan makna atau dianggap sebagai pengulangan makna dalam satu kalimat, dikategorikan sebagai kemubaziran kata. Untuk itu, bentuk tersebut diefektifkan menjadi "teman-teman saya yang bermain di halaman kosong itu" atau "banyak teman saya bermain di halaman kosong itu". Pada kalimat perbaikan tersebut sudah dihilangkan kata ulang teman-teman dan kata banyak karena keduanya bermakna nominal jamak yang sama.

Berbeda dengan penggunaan kalimat "kadang-kadang saja" sebagai kalimat penjelas dari kalimat "aku jarang bermain di pinggir hutan/gunung" adalah bentuk penggunaan kalimat tanpa konektor yang menghubungkan satu kalimat dengan kalimat yang lain. Penggunaan kalimat kadang-kadang saja bukan merupakan pengaruh BMA. Tetapi merupakan wujud keterbatasan pilihan kata (diksi) dan kemampuan mendayagunakan logika bahasa secara baik.

\section{b. Pembahasan}

\section{Penggunaan BMA sebagai Bahasa Ibu (B1) memengaruhi kemampuan Berbahasa Indonesia sebagai bahasa kedua (B2) dalam ranah keterampilan berbicara}

Berdasarkan hasil wawancara peserta didik pada kelas VIII SMP Negeri 7 Ambon menggunakan BMA sebagai bahasa ibu (B1) dan bahasa Indonesia sebagai bahasa kedua (B2). Belum tampak penggunaan B3 dan B4 dalam proses pembelajaran. Bahasa ibu (B1) yang dikuasai adalah BMA, dan bahasa kedua (B2) adalah bahasa Indonesia.

Hasil observasi terhadap penggunaan bahasa lisan dalam proses pembelajaran menandakan adanya pengaruh BMA terhadap bahasa Indonesia. Dengan demikian, BMA sebagai B1 memiliki daya tahan yang kuat (mighty language) terhadap serangan bahasa Indonesia. Contoh penggunaan BMA dalam proses belajar mengajar di SMP Negeri 7 Ambon, yaitu (1) katong kerja dengan teman ka sandiri-sandiri? (tutur 3, PB1PB2, 1), (2) Lusi, se pung dunia suda (tutur 6, PB1PB2, 1), dan (3) beta lai sudah, ibu (tutur 6, PB1PB2, 2). 
Penggunaan kosakata BMA seperti katong "kami, kita", ka? "kah?", sandirisandiri "sendiri-sendiri", se pung "bagian Anda", dan beta lai "saya juga". Bentuk BMA tersebut merupakan penggabungan BMA dengan Bahasa Indonesia dalam situasi resmi dan formal oleh peserta didik dalam pembelajaran, yang semestinya adalah ranah bahasa Indonesia. Hal tersebut, juga dialami oleh anak-anak usia 6 tahun di Desa Holimombo Jaya Kabupaten Buton yang menggabungkan bahasa Cicia dengan bahasa Indonesia karena tidak menguasai kata "orang" dalam bahasa Ciacia. Sebagaimana contoh berikut, olang katowa buku "orang gemuk". Anak tersebut berusia 6 tahun mengujarkan kata "orang" sebagai "olang", fonem /r/ diujarkan sebagai /1/ adalah bahasa Indonesia. Sedangkan katowa buku adalah bahasa Ciacia. Bentuk penggunaan bahasa Ciacia dan bahasa Indonesia tersebut, menurut Nurlaila (2016, hal 117) hal itu adalah bentuk pengaruh bahasa Ciacia terhadap bahasa Indonesia.

Penggunaan B1 dan B2 dalam proses pembelajaran pada peserta didik di kelas VIII SMP Negeri 7 Ambon sebagai dampak dari adanya keragaman bahasa yang dikuasai. Mahmud, (2008, hal 306) menjelaskan bahwa keanekaragam bahasa dan budaya di Indonesia memengaruhi penggunaan bahasa seorang anak pada tahun selanjutnya terutama bahasa Indonesia sebagai bahasa nasional dan bahasa resmi negara. Dicontohkan keanekaragaman bahasa daerah misalnya anak yang beribu dari daerah Sekayu, ayahnya dari Pagaralam dan keluarga tersebut hidup di lingkungan orang Palembang. Ibu mengujarkan kata "mengapa", dengan dialek Sekayu ngape (e dibaca kuat), ayah anak itu mengujarkan sebagai ngape (e dibaca lemah), dan di Palembang diujarkan ngapo. Dilema muncul pada waktu anak tersebut bersekolah, di mana anak itu berteman dengan anak-anak orang Jawa dan mengucapkan ngopo atau nopo. Kondisi keanekaragaman sosiolinguistik tersebut memaksa anak menetapkan salah satu dialek atau pun bahasa yang harus digunakan oleh si anak. Berdasarkan hal tersebut, bahasa daerah siswa di SMPN 1 Geulumpang Baro Kabupaten Pidie secara bersamaan memengaruhi bahasa Indonesia.

Bahasa Indonesia sebagai bahasa nasional dan sebagai bahasa negara kesatuan Republik Indonesia dan BMA sebagai bahasa daerah, masing-masing memiliki kemampuan untuk bertahan dan memengaruhi. Bahasa Indonesia sebagai bahasa resmi negara dan bahasa nasional memiliki kekuatan untuk menerobos BMA. Sebaliknya, BMA juga memiliki kekuatan untuk bertahan bahkan mampu memengaruhi keberadaan bahasa Indonesia. Keuntungan dari posisi BMA dan bahasa Indonesia seperti itu adalah adanya kontak bahasa, yang berdampak pada saling memerkaya kosakata kedua bahasa.

Kondisi sepert itu dialami oleh peserta didik di Serawak Malasyia, di mana B1 dalam hal ini adalah bahasa Malasyia memengaruhi kemampuan berbahasa Inggris. Hal tersebut terjadi karena bahasa Malasyia merupakan bahasa negera dan bahasa nasional memiliki nilai budaya dan keadaban yang tinggi bagi warga negara Malasyia. Keberadaan bahasa Inggris bagi warga Malasyia merupakan bahasa penting kedua setelah bahasa Malasyia. Oleh karena itu, tidak penting bagi warga negara Malasyia untuk berbicara menggunakan bahasa Inggris seperti para native speakers (Suliman, 2014).

Berdasarkan penjelasan tersebut, peserta didik yang menguasai B1 secara baik pada tataran keterampilan berbicara, maka B1 tersebut mampu memengaruhi penggunaan B2. Walaupun adanya harapan pemerintah RI agar bahasa Indonesia wajib digunakan dalam situasi resmi dan formal. Namun kekuatan B1 untuk bertahan bahkan memengaruhi B2 apabila peserta didik menguasai B1 secara baik dan digunakan setiap hari. Untuk menjembatani harapan pemerintah RI, agar bahasa Indonesia wajib digunakan dalam situasi resmi dan formal, maka guru harus mampu menjadi role model bagi penggunaan bahasa Indonesia di sekolah. Guru jangan bersikap apatis terhadap kebiasaan peserta 
didik yang salah (error) atau keliru (mistake) menggunakan bahasa daerah pada situasi yang resmi dan formal. Namun demikian, peran bahasa Indonesia di sekolah jangan sampai mematikan perkembangan bahasa daerah sebagai kearifan lokal maupun kearifan nasional yang seharusnya tetap hidup, dan tidak punah di telan kekuatan arus globalisasi, dan perkembangan teknologi informasi.

\section{Penggunaan BMA sebagai Bahasa Ibu (B1) memengaruhi kemampuan Berbahasa Indonesia sebagai bahasa kedua (B2) dalam ranah keterampilan menulis}

Hasil analisis data penggunaan BMA sebagai B1 dan bahasa Indonesia sebagai B2 dalam ranah tulisan menunjukan bahwa BMA memengaruhi bahasa Indonesia ranah tulis pada peserta didik kelas VIII SMP Negeri 7 Ambon. Pengaruh BMA terhadap bahasa Indonesia tersebut dapat dilihat pada kalimat yang dilingkari dalam karangan deskripsi peserta didik 01 sampai 13 pada subbab 2 penggunaan BMA sebagai B1 memengaruhi B2 dalam ranah keterampilan menulis.

Penggunaan BMA seperti kata ulang daera-daera merupakan bentuk lisan. Dalam ujaran lisan, bagi penutur tidak penting membunyikan [-h] pada akhir suku kata karena tidak berpengaruh pada makna kata, artinya tanpa membunyikan [-h] pun kata ulang daera-daera diapahami oleh pendengar adalah kata ulang "daerah-daerah" yang diakhiri fonem [-h]. Jika dilihat dari sisi kebakuan berbahasa Indonesia maka bentuk kata daeradaera merupakan bentuk lisan yang tidak terikat dengan kebakuan bahasa. Bentuk seperti itu ditemukan dalam bahasa Jawa lisan seperti, e mmas kapan nikahnya? (Pulp, 2020, hal 8). Penutur menyebut kata mas "kakak laki-laki dalam bahasa Jawa" sebagai e mas. Bentuk e mas tersebut bersifat ambigu karena secara lisan terdengar seperti kata emas "logam mulia". Demikian pula ujaran bahasa Buton lisan oleh generasi Buton usia 80-an di Kota Ambon, dalam ujaran meluluhkan suku kata akhir, misalnya kata doro "dorong", geroba "gerobak", pelabuha "pelabuhan", katora- dari kata katorang "kami, kita". Bila diperhatikan, bentuk-bentuk tersebut terjadi pengurangan/ penghilangan suku kata akhir.

Penghilangan unsur tertentu dalam tataran fonologi dikenal dengan istilah zeroisasi. Bentuk zeroisasi dibagi atas tiga jenis yaitu (1) aferesis, adalah penghilangan suku kata/ fonem tertentu pada awal kata misalnya "tetapi" menjadi tapi, "tidak akan" takan, (2) apokop, adalah penghilangan suku kata/ fonem tertentu pada akhir kata misalnya "ambil saja" menjadi ambi aja atau ambe sa, "protest" menjadi protes, dan (3) sinkop, penghilangan suku kata/ fonem tertentu di tengah kata misalnya "baharu" menjadi baru, "dahulu" menjadi dulu (Muslich, 2009).

Selain itu, penggunaan bahasa lisan juga tidak memedulikan kelogisan bahasa. Misalnya, saya mengajar mata kuliah Jurnalistik Online di kampus. Kalimat tersebut tidak logis, karena yang diajari bukan mahasiswa tetapi mata kuliah, padahal mata kuliah tidak bisa diajari. Untuk itu, kalimat tersebut dilogiskan menjadi "saya mengajrkan mata kuliah Jurnalistik online di kampus". Dengan demikian, yang membuat kalimat tersebut menjadi logis adalah penggunaan sufik [-kan], yang berbeda fungsi dengan sufiks [-i], dan kata mengajar tidak menggunakan sufik (Pulp, 2020:9).

Karangan deskripsi oleh peserta didik kelas VIII SMP Negeri 7 Ambon, ditemui bentuk-benuk tidak logis yang merupakan pengaruh BMA lisan. Misalnya, (1) Aku sering bermain di pinggir pantai Desa Wayame. (2) Aku jarang bermain di pinggir hutan/gunung. (3) Kadang-kadang saja. Teks tersebut dilogiskan melalui penghilangan kalimat nomor 3. Sehingga kalimat nomor 1 dan 2 secara tegas dan jelas bahwa penutur sering bermain di pinggir pantai Desa Wayame dan jarang bermain di pinggir hutan/gunung. 
Berdasarkan penjelasan-penjelasan tersebut, pernyataan bahwa BMA sebagai B1 memengaruhi bahasa Indonesia sebagai B2, didasarkan pada pengategorian sifat keterampilan berbahasa yang terdiri atas 4 komponen, yaitu (1) keterampilan mendengarkan/ menyimak, (2) keterampilan berbicara, (3) keterampilan membaca, dan (4) keterampilan menulis. Keterampilan menulis merupakan keterampilan terakhir/ tertinggi yang dikuasai setelah keterampilan mendengarkan/menyimak, keterampilan berbicara, dan keterampilan membaca. Keterampilan menulis dan berbicara merupakan keterampilan yang bersifat produktif (menghasilkan) bahasa, disebut juga keterampilan berbahasa aktif. Keterampilan mendengarkan/menyimak dan membaca bersifat reseptif (menerima bahasa) disebut juga keterampilan berbahasa pasif (literasi.com, 2019).

Berdasarkan penjelasan tersebut, penelitian ini telah mengeksplanasi keterampilan berbahasa secara produktif/ aktif (menghasilkan) bahasa. Dengan demikian, sudah termasuk di dalamnya keterampilan berbahasa pasif. Sebagaimana peristiwa tuturan pada dialog antara peserta didik dan guru pada PB1PB2 1 dan PB1PB2 2. Sebelum peserta didik menjawab pertanyaan dan pernyataan guru, terlebih dahulu peserta didik mendengar/ menyimak tuturan guru. Demikian pula, pada ranah keterampilan menulis dan membaca. Kedua keterampilan tersebut terjadi secara simultan, karena peserta didik pada saat menulis maka secara simultan proses membaca juga sedang berlangsung. Menulis dan membaca tidak dapat dipisahkan, karena seseorang bisa menulis apabila sudah dapat membaca.

\section{Faktor-Faktor Penyebab Peserta Didik menggunakan BMA Sebagai Memengaruhi Bahasa Indonesia Sebagai (B2)}

Berdasarkan penjelasan pada bagaian analisis data terdeskripsi bahwa beberapa faktor yang menyebabkan peserta didik pada kelas VIII SMP Negeri 7 Ambon menggunakan BMA sebagai B1 memengaruhi Bahasa Indonesia sebagai B2. Faktorfaktor tersebut adalah (1) faktor kedwibahasaan, dan (2) faktor migrasi dan urbanisasi (baca Rumalean, dkk., 2020). Berdasarkan penjelasan tersebut, penelitian ini memperkuat dan menambahkan satu lagi faktor yang melatari penggunaan BMA dalam memengaruhi bahasa Indonesia. Hasil penelitian Rumalean, dkk., (2020) menjelaskan bahwa ada dua yang melatari penggunaan BMA memengaruhi bahasa Indonesia yaitu kedwibahasaan dan migrasi, maka penelitian ini menambahkan satu faktor lagi yaitu urbanisasi.

Pertama faktor kedwibahasaan; hasil analisis menunjukan bahwa peserta didik di SMP Negeri 7 Ambon menguasai BMA dan Bahasa Indonesia. Kedua bahasa tersebut digunakan secara bersamaan dalam proses pembelajaran di sekolah. Orang yang menguasai dan menggunakan dua bahasa disebut dwibahasawan. Orang yang menguasai tiga bahasa atau lebih disebut ekabahasawan. Kata dwibahasawan dan ekabahasawan merupakan kata benda (nomina). Fenomena penggunaan bahasa secara dwibahasa maupun ekabahasa disebut kedwibahasaan dan keekabahasaan, keduanya termasuk kata sifat (adjektiva) (Hastuti, 2013).

Masyarakat Indonesia pada umumnya dwibahasawan karena menguasai bahasa daerah masing-masing dan juga menguasai bahasa Indonesia (Pranowo, 2014). Selain itu, ada juga yang ekabahasawan seperti Gayatri Wailisa (Almarhum) yang semasa hidupnya menguasai 19 bahasa, 14 bahasa dikuasai secara fasih, 5 bahasa sedang proses menuju fasih. Tetapi Allah Swt berkehendak lain, Gayatri Wailisa meninggal dunia di Jakarta pada 23 Oktober 2014 dalam usia 17 tahun. Jasadnya dikebumikan di Taman Makam Pahlawan Kapaha Ambon.

Selanjutnya, peserta didik pada kelas VIII SMP Negeri 7 Ambon menguasai secara baik BMA diikuti dengan bahasa Indonesia. Secara psikologis penggunaan BMA peserta 
didik pada sebagian besar waktu di luar sekolah. Oleh karena itu, peserta didik tidak bisa meninggalkan habitus tersebut dalam waktu singkat. Kebiasaan yang telah menjadi zona nyaman, sulit ditinggalkan dalam waktu yang singkat. Zona nyaman tersebut terdegradasi seiring perjalanan waktu. Kedwibahasaan tidak dipandang dari segi seorang penutur menguasai secara baik dua bahasa, melainkan penutur tersebut menggunakan dua bahasa yang dikuasai secara bersamaan dalam tuturan. Ghasya (2018, hal 129-130) menjelaskan bahwa siswa kelas VI SD N 1 Galagamba tergolong dwibahasawan karena menggunakan bahasa Cirebon bersamaan dengan bahasa Indonesia di kelas.

Faktor kedua ialah migrasi dan ubanisasi; kota Ambon sebagai pusat pemerintahan Pemda Kota Ambon dan Pemda Provinsi Maluku. Selain sebagai pusat pemerintahan juga pendidikan, ekonomi, dan sosial budaya menjadikan Kota Ambon sebagai magnet bagi masyarakat 11 kabupaten dan kota di Provinsi Maluku, maupun masyarakat dari daerah lain di Indonesia untuk datang ke Ambon dengan beragam tujuan. Ada yang menetap karena bekerja, dan ada yang bersifat musiman.

Masyarakat pendatang dengan tujuan bekerja dari 11 kabupaten/kota di Provinsi Maluku yang kemudian menetap sebagai warga Kota Ambon disebut warga urban. Warga urban itulah yang kemudian putra/putrinya lahir, besar, dan bersekolah di Kota Ambon. Putra-putri para urban tersebut umumnya menguasai BMA secara baik, karena seharisehari di lingkungan sekitar menggunakan BMA.

Para keluarga urban dari 11 kabupaten dan Kota tersebut memiliki beragam bahasa daerah. Misalnya, di Kabupaten Buru dan Buru Selatan di Pulau Buru terdapat bahasa Buru, bahasa Ambalau, dan bahasa Kayeli. Di Kabupaten Maluku Tenggara dan Kota Tual di kepulauan Kei ada bahasa Kei dan bahasa Banda. Di Kabupaten Kepulauan Tanimbar ada bahasa Tanimbar dan bahasa Fordata. Di Kebupate Kepulauan Aru ada bahasa Dobo dan ada bahasa Tarangan. Di Kabupaten SBT, SBB, dan Maluku Tengah di Pulau Seram, ada Bahasa Geser-Gorom, bahasa Werinama, bahasa Bati, bahasa Bobut, bahasa Beun, bahasa Hoti-Banggoi, bahasa kesyui, dan bahasa Teor, bahasa Wemale, bahasa Alune, bahasa Luhu, bahasa Amahai, bahasa Naulu. Kota Ambon di pulau Ambon ada bahasa Hitu atau bahasa Leihitu. Di Kepulauan Lease ada bahasa Hatuhaha, bahasa Iha, dan bahasa Saparua.

Warga Kota Ambon umumnya berasal 11 Kabupaten/ Kota di Maluku yang memiliki bahasa daerah masing-masing. Warga urban tersebut menyebar di Kota Ambon pada empat wilayah kecamatan yaitu Kecamatan Nusaniwe, Kecamatan Baguala, Kecamatan Teluk Dalam, dan Kecamatan Sirimau. Untuk berkomunikasi di antara para urban maupun dengan keluarga masyarakat pulau Ambon yaitu Lehitu dan Leitimur maka BMA menjadi lingua franca. Oleh karena itu, BMA menjadi pristesi tersendiri bagi warga pulau Ambon maupun para urban.

\section{KESIMPULAN}

Semakin baik penggunaan bahasa daerah yang kuasai oleh peserta didik dan guru, maka pengaruh penggunaan bahasa daerah tersebut semakin kuat terhadap bahasa Indonesia. Sebagaimana penggunaan BMA sebagai B1 memengaruhi bahasa Indonesia sebagai B2. Hal tersebut terjadi pada peserta didik di kelas VIII SMP Negeri 7 Ambon menggunakan Bahasa Melayu Ambon (BMA) dan bahasa Indonesia dalam tataran lisan dan tulisan. Tataran lisan digunakan pada saat proses pembelajaran dan tataran tulisan dalam karangan deskripsi. Penggunaan BMA memengaruhi bahasa Indonesia atas latar belakang, (1) faktor kedwibahasaan, dan (2) faktor migrasi dan urbanisasi. Faktor kedwibahasaan terjadi manakala BMA dan bahasa Indonesia digunakan secara bersamaan dalam proses tuturan antara peserta didik dan guru dalam proses pembelajaran. 
Faktor migrasi dan urbanisasi penduduk dari kabupaten/ kota atau daerah-daerah di Provinsi Maluku ke Kota Ambon, menyebabkan BMA digunakan sebagai lingua franca di antara warga Kota Ambon yang beragam latar belakang perbedaan bahasa daerah.

Keragaman bahasa yang dimiliki peserta didik pada kelas VIII SMP Negeri 7 Ambon memaksa peserta didik menggunakan BMA untuk saling berkomunikasi. Bila terjadi kontak antar bahasa, maka terjadi saling pengayaan kosakata melalui sistem pengadopsian kata bagi kedua bahasa. Kontak bahasa terjadi antara BMA dan bahasa Indonesia melalui peserta didik kelas VIII SMP Negeri 7 Ambon dalam proses pembelajaran bahasa Indonesia. Dampak dari proses kedwibahasaan adalah penggunaan unsur daerah dalam bahasa Indonesia pada situasi resmi atau formal. Untuk mengurangi dampak tersebut, guru diharapkan menjadi role model penggunaan bahasa Indonesia yang baik dan benar.

\section{UCAPAN TERIMA KASIH}

Peneliti menyampaikan terima kasih kepada Rektor Universitas Pattimura dan Dekan FKIP Unpatti yang memberikan kesempatan kepada tim peneliti memanfaat anggaran Hiba FKIP tahun 2020/2021. Terima kasih juga disampaikan kepada Kepala Lemlit Unpatti dan anggota yang melaksanakan tugas sebagai reviwer internal dalam mengaudit hasil penelitian ini.

\section{REFERENSI}

Creswell, J. W. (2015). Penelitian Kualitatif dan Desain Riset Memilih di Antara Lima Pendekatan (Edisi ke-3). Alih Bahasa Ahmad Lintang Lazuardi, dari judul asli Qualitative Inquiri \& Research Design: Choosing Among Five Apphroches, Third Edition Firts Published 2013. Jakarta: Pustaka Pelajar.

Erniati. (2019). Penguasaan Leksikon Arkais Bahasa Melayu Ambon di Kalangan Pemuda di Kota Ambon. Jurnal Gramatika. Volume VII (1) Januari-Juni 2019, 28-48. Diperoleh pada Desember 020 dari http://gramatika.kemdikbud.go.id/index.php/gramatika/article/download/180/11 $\underline{6}$.

Hastuti, S. (2003). Sekitar Analisis Kesalahan Berbahasa Indonesia. Yogyakarta:Mitra Gama Widya.

Kusmawanto, Y. N., Indrie, D.F., Heri, I. (2019). Pengaruh bahasa Ibu terhadap Penggunaan Bahasa Indonesia pada Pidato Persuasif di SMP Negeri 2 Batujajar. Parole (Jurnal Pendidikan Bahasan dan Sastra). Volume 2(3) Mei 20019, 461466. Diperoleh pada Desember 2020, dari file:///C:/Users/ASUS/AppData/Local/ Temp/2849-6184-1-PB.pdf.

Literasi.com. (2011). 4 Keterampilan Berbahasa yang perlu dikuasai. Literasi.com. Diperoleh dari https://literasinusantara.com/4-keterampilan-berbahasa/, pada 10 Januari, 2021.

Mahmud, T. (2018). Pengaruh Bahasa Daerah Terhadap Penggunaan Bahasa Indonesia Secara Bersamaan pada Siswa di SMPN 1 Geulumpang Baro Kabupaten Pidie. Internal Proceding Seminar Nasional Pendidikan Dasar, hal 302-314. Diperoleh 
pada Desember 2020, dari https://repository.bbg.ac.id/bitstream/ 707/1/035_TEUKU_MAHMUD.pdf.

Muslich, M. (2009). Perubahan Bunyi dalam Bahasa Indonesia. Artikel-Fakultas Sastra Universitas Malang-Jawa Timur. Diperoleh pada Januari 2021, dari http://muslichm.blogspot.com/2009/03/perubahan-bunyidalam-bahasa-indonesia.html.

Moleong, J. L. (2008). Metodologi penelitian kualitatif. Bandung: Remaja Rosdakarya.

Nurlaila, M. (2013). Pengaruh Bahasa Daerah (Ciacia) Terhadap Perkembangan Bahasa Indonesia Anak Usia 2 Sampai 6 Tahun Di Desa Holimombo Jaya. Jurnal Retorika. Volume 9(2), Agustus 2016, 90-163. Diperoleh pada Desember 10, 2020, dari file://C:/Users/ASUS/AppData/Local/Temp/3801-9406-1-PB.pdf.

Rumalean, I., Novita T., Yohanes H., dan Hajija S. (2020). Analisis Pemerolehan Kesalahan Berbahasa dalam Pembelajaran Bahasa Indonesia Peserta Didik Kelas VIII SMP Negeri 7 Ambon, Jurnal Belajar Bahasa, Volume 5(1) Februari, 20-2020, hal 63-72.

Pranowo. (2014). Teori Belajar Bahasa. Yogyakarta: Pustaka Belajar.

Pulp. (2020). Contoh Kalimat yang Dipengaruhi Bahasa Daerah. PULP, 08-09-2020. Diperoleh pada Januari 2021, dari https://cermin-dunia.github.io/pulp/post/contohkalimat-yang-dipengaruhi-bahasa-daerah/

Syamsudin, A. R., Damaianti, V. S. Metode Penelitian Pendidikan Bahasa. Jakarta: PT. Remaja Rosdakarya.

Sugiyono. (2005). Memahami penelitian kualitatif. Bandung: Alfabeta.

Suliman, A. (2014). The Interference of Mother Tongue/Native Language in One's English Language Speech Production. International Journal of English and Education, Volume 3(3), 356-366, Retrieved July 2014, from https://www.researchgate.net/publication/319892549_International_Journal_of_En glish_and_Education_The_Interference_of_Mother_TongueNative_Language_in One's_English_Language_Speech_Production. 
